\title{
Study on the Communicative Competence Cultivation in English Teaching
}

\author{
$\mathrm{Na} \mathrm{Li}$ \\ (Jiangxi Science \& Technology Normal University, Nanchang, 330038)
}

\begin{abstract}
Keywords: Current Condition; Communicative Approach; College Oral English Teaching
\end{abstract}
\begin{abstract}
It is known to all that language is a communication tool with social communicative functions. Communicative competence was firstly put forth by an American sociolinguist called Dwell Hymes. In his opinion, communicative competence is not only about understanding and mastering a language, but understanding and mastering when, where and how to use proper language to communicate. As we have entered 21 century while globalization is approaching, so the world is getting smaller. Based on this, the communication, connection and mutual influence in all aspects are progressing. During the process of communication, English, as a global language, plays a pivotal role. English acts as the bridge of communication all over the world and is deemed as an important tool and means of communication.
\end{abstract}

\section{Introduction}

Based on the most essential function of languages, the goal of foreign language teaching is to cultivate the communicative competence of students, namely, the ability to use oral language to express themselves. Since the reform and opening up of China, the economy has boomed with a strong power. Continuous, rapid, and deep development has challenged talents based on higher requirement while English communicative competence stand in the breach. It is worth mentioning that the oral communicate competence is highlighted. However, due to the profound influence of traditional and exam-oriented education, English teaching was mainly for cultivating students' language knowledge while the oral communicative competence has been ignored for a long time. As a result, a glittering array of students cannot communicate with basic English after college graduation even though they have spent a lot of efforts on it. So, they are far behind the requirement put forward by the government and society. In the recent decades, the teaching outline and materials have been modified various times and relevant education departments have asked to focus on cultivating students' oral communicative competence so as to satisfy the urgent need of qualified talents. Sadly, the result is not satisfying. So, lots of people think that it is impossible to implement communicative language teaching in China because it is not adapted to the Chinese society. The author holds a different idea: communicative teaching takes cultivating communicative competence as the ultimate goal to replace traditional teaching method. In addition, to take advantage of communicative activities to cultivate students' oral communicative ability is an effective way to solve current problems.

\section{Current Condition of College English Teaching Reform}

The current teaching mode of college English has been worked for a long time, which is entrenched. Judging from the nation, college English teaching has always been exam-oriented, focusing on CET 4 and CET 6. The reason why students learn English is to pass exams and the role teachers act is to guide them how to pass those exams and improve the pass rate. In the meanwhile, the evaluation on teachers is carried out based on this and the society judge students based on those exam certificates or they will not even look at their resumes. As a result, CET 4 and CET 6 exams are considered as invisible shackles, limiting the innovative teaching methods of teachers.

Among diverse teaching theories and modes, we take communicative competence as the goal while the combination of studying and applying has received wide recognition among teachers. At present, teachers adopt communicative activities including group chat, roles playing, debate etc. in 
communicative classes to help students overcome the learning anxiety and strengthen confidence. What's more, a series of language communicative activities will be adopted to improve the language acquisition.

However, it is not easy to carry out teaching reform based on our current teaching practice which needs the mutual efforts from education departments, schools, teachers and students. In terms of teachers, they should improve in the following aspects: to begin with, change the traditional teaching mode and take communicative teaching as the guide. Looking back to my experience from elementary to college, all my teachers adopt expository teaching. Now, I am a teacher and I have adopted this teaching method for a decade. However, it is not easy for me to reflect my teaching method now and change my teaching practice. Therefore, we cannot become eager for quick success and instant benefit, but we should implement reform step by step and focus on communicative interaction while keeping the advantages of traditional teaching. After all, students are still facing the pressure of exam and employment. Furthermore, excessive communication as well as interaction will occupy students' learning time for exam. Secondly, teachers should change the class teaching mode and take intensive reading as one of the sources. Moreover, practice classes including communication and language application should be increased to cultivate students.

\section{Rules English Communicative Teaching Should Obey}

\section{Principle of Interaction}

Class teaching is an joint activity between teachers and students as well as students and students. Therefore, teachers should create a bilateral and multidirectional English information exchange environment, acting as an equal participant. In addition, teachers should encourage students to speak English and take it as a habit. Under the guidance of teachers, students should take the initiative to participate and teachers should play the leading role while students should be the main focus. That is to say, teaching should be carried out based on reality, and understand the psychological needs of students so as to try the utmost to create an equal class environment. Based on this, students will feel free to receive and release information.

\section{Principle of Developing an Interest}

Interest can be considered as the best teacher. Only by stimulating students' interest in oral communication, can the teaching and training be effective. Therefore, teachers should have passion to ignite students' interest with an amiable attitude so as to create a democratic, harmonious, and relaxing environment. What's more, teachers should also try the utmost to develop course resources and put forward topics, build a platform to encourage group chatting, drama performance etc. to closely integrate diversified teaching methods with colorful after-class activities. As a result, students are given more opportunities to express themselves and they will gradually become interested in oral communication.

\section{Principle of Flexibility and Normativity}

Formulaic dialogue and class language cannot stimulate students' interest and passion. What's more, there are no deep communications between teachers and students. In order to realize real communicative activities, teachers have to flexibly and accurately use English. During the process, they should also combine concrete conditions and adopt different expressions to demonstrate. Only by this way, can they help to use languages more flexibly and correctly. At the same time, students will find it easy to better understand rather than being boring.

\section{Enlightenment for College English Teaching Based on Communicative Teaching Methods}

To begin with, there is a challenge for teachers because of the conflict between teaching and learning. The teaching evaluation method implemented at school is not proper and are not good for teachers. As a result, it will create a bad effect on the enthusiasm of teachers. For example, some schools evaluate teachers based on the scores students gave and some students are emotion-oriented. If teachers are strict, they are tend to give a lower score, which will affect teachers for them to be 
passionate for contributing to work.

Secondly, the wrong positioning of teaching target. In most of colleges, managers always hold the idea that if the grade of CET 4 and pass rate are improved, the English teaching is effective and improved. What's more, some colleges tie CET 4 certificate with graduation certificate. If you cannot pass CET 4, you cannot be granted the graduation certificate. In the meanwhile, teachers of other subjects cannot well understand the college English teaching and why is English teaching associated with CET 4 and 6.

Thirdly, the human resource department of enterprises pay attention to CET 4 and 6 certificates, which actually limits teachers to implement teaching reform. It is very difficult to carry out teaching reform if this condition cannot be changed. The education condition nowadays is formed based on the education department, schools, teachers and students while the improvement of college students' English ability needs cooperation and support from various aspects of the society. If schools can implement bilingual teaching for core courses, then teachers' stress will be reduced to a big extent. Then, we can have time and space for cultivating students' communicative ability and then our teaching goal will be realized.

\section{Conclusion}

Language is a tool for communication and the goal to learn a language is to acquire the ability to carry out communications. What's more, while learning English we have to understand and use English, rather than showing off. Therefore, during the teaching process, teachers have to carefully understand the teaching outline and design communicative activities so as to guide them to participate in. As the tutor, teachers should also combine various English teaching methods, make up for each other's deficiencies and focus on cultivating their communicative abilities. Only when teachers adopt correct teaching methods, focus on cultivating communicative abilities, can we help to improve students' English ability. Of course, students should also refer to their reality to set up a proper learning mode so as to acquire extensive knowledge, fulfill their brain and broaden their horizon. Based on that, can they contribute to the exchanges as well as development in terms of national politics, economy, culture and science.

\section{References}

[1] Yildirim O. The Effect of Teaching Experience on English Language Teachers' Perceptions of Learners' Listening Comprehension Problems[J]. Theory \& Practice in Language Studies, 2015,5(4):694.

[2] Volk H,Kellner K,Wohlhart D. Learning Analytics for English Language Teaching[J]. Journal of Universal Computerence,2015,21(1):156-174.

[3] Iyitoğlu O,Alci B. A Qualitative Research On 2ND Grade Teachers' Opinions About 2ND Grade English Language Teaching Curriculum[J]. 2015,14(2).

[4] Uztosun M S. Lecturers' views of curriculum change at English language teaching departments in Turkey[J]. 2015,9:15-29.

[5] Early M, Kendrick M,Potts D. Multimodality: Out From the Margins of English Language Teaching[J]. Tesol Quarterly,2015,49(3):447-460.

[6] Mirhosseini S A,Samar R G. Ideologies English Language Teaching in Iranian Academic Research: Mainstream,Alternative, and Beyond[J]. Critical Inquiry in Language Studies,2015,12(2):110-136.

[7] Hutabarat P. The Relationship betwen Second Language Acquisition Process and English Language Teaching in Indonesia[J]. 2016,1(2).

[8] Demiroz H,Yesilyurt S. Effective Foreign Language Teaching: Perceptions of Prospective English Language Teachers.[J]. Universal Journal of Educational Research,2015,3(11):862-870.

[9] Akdemir A S,Eyerci A. English Language Teaching or Teaching English Language Grammar: An Investigation of Focus on Grammar[C]// Elt Research Conference. 2016. 
[10]Blyth A. Social Media Ethics in English Language Teaching.[J]. Jalt Call Journal,2015,11.

[11]Al-Enzy M,Jesudas R. Productive Oral Feedback - A Successful Tool in English Language Teaching[J]. 2016,4(2):317.

[12] Selvi A F,Rudolph N,Uzum B. Equity and Professionalism in English Language Teaching: A Glocal Perspective[M]// Social Justice in English Language Teaching. 2016. 